\title{
Specialised fictional narrative and lay readership: Bridging the accessibility gap
}

\section{Shaeda Isani}

\section{(2) OpenEdition}

1 Journals

\section{Electronic version}

URL: http://journals.openedition.org/asp/129

DOI: $10.4000 / a s p .129$

ISBN: 978-2-8218-0410-4

ISSN: 2108-6354

\section{Publisher}

Groupe d'étude et de recherche en anglais de spécialité

\section{Printed version}

Date of publication: 1 November 2009

Number of pages: $45-65$

ISSN: 1246-8185

\section{Electronic reference}

Shaeda Isani, "Specialised fictional narrative and lay readership: Bridging the accessibility gap », ASp [Online], 56 | 2009, Online since 01 November 2012, connection on 02 November 2020. URL : http:// journals.openedition.org/asp/129; DOI : https://doi.org/10.4000/asp.129

This text was automatically generated on 2 November 2020.

Tous droits réservés 


\title{
Specialised fictional narrative and lay readership: Bridging the accessibility gap
}

\author{
Shaeda Isani
}

1 "Vulgarisation" or "popularisation" of specialised knowledge and discourse is a wellestablished line of enquiry in the field of mediated communication, notably with regard to hard sciences. Such studies have focused essentially on the educational purposes of vulgarisation and analysed scientific texts produced for textbooks, general public science magazines, newspaper articles, etc. In a paradigmatic shift from education to entertainment, this article proposes to study vulgarisation processes and procedures in a relatively less explored domain, that of popular fiction. In so doing, it also proposes to extend the habitually scientific-orientated scope of analysis in vulgarisation studies to include other subject-domains present in contemporary popular fiction, such as art and law, for example.

2 Popular fiction, which covers such subgenres as thrillers, adventure stories, historical novels, romances, science-fiction and even graphic novels, is, as Ken Gelder states, "best conceived as the opposite of Literature. The reverse is also true and, in fact, it can often seem as if Literature and popular fiction exist in a constant state of mutual repulsion or repudiation." (2004: 11). According to a common adage, authors of literary fiction write for themselves, while authors of popular fiction write for their readership, the former is thus author- and idea-driven, while the latter is entertainment- and reader-driven. In spite of such binary categorisation, some authors straddle the divide and, in this respect, Iain Pears, provides a fitting point of reference in that, under the same name, he writes both "serious" historical and philosophical works of fiction as An Instance of the Fingerpost (1998), and The Dream of Scipio (2002), and a series of popular art FASP he calls his "light and fluffies." (Isani 2004: 80)

3 This divide between high and low culture finds a strong echo in Pierre Bourdieu's (1992) view that high culture caters to an elite audience of a like-minded "happy few" and thus places itself above and independent of the general public and related 
consumerism and market considerations, while low culture, being highly dependent on mass consumption, is produced with its 'consumer', whether audience or reader, in mind. Such discursive genres, as Beacco et al. point out, "can no longer be defined by their relationship to the discourse source, but by their readership and, for some of them, by the status of texts as commodities - texts meant for consumption." (2002: 279)

In view of such tendencies, literary criticism tends largely to focus on the author or the text, while the addressee of the text, the reader, is a comparatively marginalised line of enquiry. This study proposes to reinstate the reader as an active participant in the author-narrative-reader triangulation. We first focus on narrative by providing an overview of what is meant by "specialised fictional narrative", followed by a brief analysis of the factors which render such texts more or less reader-accessible. We next focus on the reader and propose a typology of readership profiles based on ability to access specialised text. And finally, we examine the authorial techniques deployed to attain the opposed objectives of reflecting and enhancing the author's status as an expert while at the same time catering to a lay readership's need for accessible discourse.

\section{Specialised fictional narrative or FASP}

\subsection{Genre overview}

5 Research in the area of specialised fictional narrative has attracted considerable interest since it was given generic status as fiction à substrat professionnel or FASP in 1999 by Michel Petit. The new genre was defined in terms of four broad defining conventions: its status as popular fiction; its contemporary setting; ${ }^{1}$ its appurtenance to the thriller genre; ${ }^{2}$ and finally, the professional or specialised environment which shapes plot, character and dénouement, the substrat professionnel.

6 Earlier references to the existence of such a literary trend do exist, as evidenced by Scott McCracken's observation: "A significant, postmodern characteristic of contemporary bestsellers is their self-reflexive quality. In fact, they commonly take as their subject the industry of which they are a product, Hollywood, large corporations, television, hotels, retail, airports, casinos and horse-racing are frequent settings [...]" (1998: 44). Nevertheless, it is Michel Petit's seminal work in identifying and bringing together an otherwise disparate body of fiction which elevated the loosely identified trend into a genre per se.

7 As Ken Gelder underlines, popular fiction is strongly genre-driven and "flaunts its generic identity" (2004: 158): romance, thriller, adventure, spy novel, fantasy, science fiction, etc. This high generic visibility is reinforced with regard to the FASP, an umbrella genre which breaks up into a variety of distinct subgenres defined by the substrat professionnel. The most abundant is undoubtedly legal FASP, not only regarding the number of authors and copies sold, but also in terms of genre subsets (lawyer FASP, judiciary FASP, jury FASP, courtroom drama...). If the best-known of legal FASP authors is undoubtedly John Grisham, other authors such as Scott Turow, John Mortimer and Natasha Cooper are also representative. Related to legal FASP is the highly popular forensics FASP which intersects with three specialist domains, science, law and police procedural. It is popular as television series (NCIS, CSI, Bones, Silent Witness, etc.) but also in print, an area long dominated by the two 'Queens of Forensics', Kathy Reichs and 
Patricia Cornwell. Another major and somewhat heterogeneous FASP area is the scientific/technical field, covering military techno-thrillers (Tom Clancy), scientific FASP (Michael Crichton) and, a subgenre in its own right, medical FASP, both as television series (ER, Grey's Anatomy, Dr House, etc.), and through such popular authors as Robin Cook and Tess Gerritson. Other less abundant but nevertheless highly characteristic subgenres are journalism FASP as illustrated by authors as Stieg Larsson and Denise Mina, and art FASP as exemplified by Iain Pears or Neil Griffiths and their Italian art detective mysteries.

\subsection{Obstacles to reader accessibility}

8 The specialised nature of fictional narrative inevitably gives rise to the question of how lay readers access the language, concepts and culture of the specialised substrat professionnel that nourishes plot dynamics.

9 Subject-domain is a primary consideration in this respect. Scientific subjects are generally classified as 'hi-tech' and non-scientific subjects as 'lo-tech', as Ken Gelder states with reference to two mainstream FASP subgenres, science and law: "Although both novelists underwrite their fiction with technical information, Grisham is resolutely low-tech alongside Crichton's hi-tech interests." (2004: 112). It is clear that scientific narrative poses a dual challenge in that 'hi-tech' concepts are expressed in specific lexicon and locution, whereas, though legal concepts may also be complex, the language used to define and discuss them shares more common ground with everyday English.

'Hi-tech' fictional narrative, however, may also be found in areas of human activity not related to professional disciplines. Substrats professionnels drawn from leisure activities, such as sports, music, hobbies, etc., may generate specialised fictional narrative as illustrated by Dorothy L. Sayers' classic The Nine Tailors, a highly specialised murder mystery (considered to be amongst the finest in the British anthology of crime), whose plot, character and denouement are embedded in the esoteric technical mysteries of bell-ringing, explained to the reader as follows:

'One moment, my dear boy', he said, pushing the tobacco-jar towards his guest, 'one moment. I am just pricking this little touch to show Wally Prat how to do it. He has got himself "imbrangled" as they called it - fine old English word, that. Now what has the foolish lad done here? The ninth lead should bring Queen's change - let me see $-51732468,15734268$ - that's the first thirds and fourths all right -51372468 , 15374268 - and that's the first fourths and thirds - 13547826 - ah! here is the trouble! The eighth should be at home. What has happened? - To be sure! What a beetle-headed cuckoo I am! He has forgotten to make the bob. She can't come home till she's called.' He ran a red-ink line down the page and started to write figures furiously. 'There! 51372468, 15374268 - and now she comes home like a bird! 13572468. That's better. Now it should come round at the second repeat. I will just check it. Second to fifth, third to second - yes, yes - that brings 15263748, with Tittums at the end of the second course, and repeated once again brings it round. I will just jot down the leaf-ends for him to check it by. Second to third, third to fifth, fourth to second, fifth to seventh, sixth to fourth, seventh to eighth, eighth to sixth for the plain lead. Then the bob. Plain, bob, bob, eighth to sixth for the plain lead. Then the bob. Plain, bob, bob, three plain and a bob. Call her in the middle, in and out and home. Repeat twice. A lovely little touch.' (1959: 179-180)

11 Though popularised discourse studies tend to focus primarily on technical concepts and terminology, they are not the only obstacles to reader accessibility. ${ }^{3}$ Certain 'lo- 
tech' sources of substrat professionnel may also encounter relatively low accessibility because they are deeply culture-embedded. ${ }^{4}$ Art FASP is one such area as illustrated by the following excerpt from Neil Griffith's Saving Caravaggio in which reader accessibility is hampered not so much by lexical difficulty as by the absence of a shared cultural framework:

I am here to see Caravaggio's Salome Receives the Head of Saint John the Baptist. [...] I have come here because I want to understand from this painting in what way I might be guilty of Nenni's and Maria's deaths. [...] The painting consists of a group of four: Salome, an old woman, John, an executioner; its story is the execution of John the Baptist. Its theme is responsibility. The executioner hands over John's head in a confident gesture that declares he is not culpable for the death, he was obeying orders and was expedient and professional in the carrying out of his duties - a gesture declaring that it is time for those who ordered the execution to confront their actions. [...] This is all articulated by the distancing arm, John's head suspended by hand-gripped hair. I suspect that the executioner is pausing before placing the head on a charger held out by Salome, a pause in which Salome confronts her motives, forcing her to look away. (2006: 191)

Proceeding on the basis of a low-context approach which presumes readers possess the relevant "culture capital" - and hence, familiarity with related Biblical culture - the author does not, at any point in the narrative, contextualise the facts related to the event depicted in the painting. The entire message behind the surface lexicon of the text and its relation to the fictional narrative is hence largely lost on readers of popular fiction not familiar with the story of Salome and John the Baptist. ${ }^{5}$

Such considerations underline the fact that accessibility construed in terms of the ability to grasp meaning at the level of semantics is a relatively narrow approach. A more pragmatic approach broadens the acceptation of the notion to include the ability to understand narrative in terms of its textual and contextual structure, thus allowing for a degree of critical distance with regard to the specialised language, constructs and culture of the substrat professionnel.

\section{FASP readership profiles}

Readership studies ${ }^{6}$ have defined a host of reader profiles such as, "real", "ideal", "contemporary", "intended", "postulated", "informed", etc., to define reader interaction with the meaning of the text. Although we are not specialists of this area and in spite of a risk of oversimplification, we propose to interpret a number of these concepts with regard to reader-accessibility and the specialised constructs of the substrat professionnel. Within the framework of the wider interpretation of reader accessibility skills as discussed above, we examine four broad theoretical FASP readership profiles ranging from lay to professional: the naïve reader, the specialist reader, the informed reader and the knowledgeable reader.

\subsection{The naïve FASP reader}

This category of lay reader is devoid of any prior awareness of the specialised environment and represents a state of tabula rasa. He consequently brings to his reading an innocence and acceptance of the specialised narrative, "a willing state of belief" - as opposed to Coleridge's "willing suspension of disbelief" - imposed by an 
absence of outside reality (familiarity with the fictionalised subject-domain, in this case), which leads him to mirror the textual structure and its underlying authorial intentions.

In terms of readership studies, the naïve FASP reader may be identified with certain aspects of Wolfgang Iser's concept of the "implied reader" who

embodies all those predispositions necessary for a literary work to exercise its effect - predispositions laid down, not by an empirical outside reality, but by the text itself. Consequently, the implied reader as a concept has his roots firmly planted in the structure of the text. (1978: 34)

In the present age of ubiquitous information and mass intelligence, the question arises as to whether such a state of innocence can exist and the plausibility of a textcontrolled naïve reader. In the case of non-specialised fiction, the answer would rightly tend to be negative. Likewise, substrats professionnels drawn from human sciences, such as law, psychology, economics, etc., which are areas of activity that permeate everyday life, generate greater awareness and reader accessibility and, in the same correlation, critical distance from the specialised narrative text. Concerning such domains, as Wolfgang Iser specifies with regard to "the implied reader", "[...] the role of the text will be stronger, but the reader's dispositions will never disappear totally" (1978: 37). Conversely, the concept of a naïve reader is quite plausible regarding complex and esoteric substrats professionnels drawn from specialisms such as DNA analysis, computer technology, musicology, finance or even philosophy, for example, particularly in the case of the 'casual' FASP reader who picks up a FASP novel randomly for a 'one-off' reading, as is often the case with a genre otherwise called "airport fiction" or roman de gare.

The naïve reader's dependence on and submission to authorial intentions and textual structure is sustained by the nature and status of FASP authorship. One of the extrinsic conventions of the genre identified by Michel Petit is the specialised status of the FASP author, typically a practising professional or a professional-turned-author. Some wellknown examples are Scott Turow (lawyer), John Mortimer (barrister), Robin Cook (doctor), Iain Pears (art historian), Kathy Reichs (forensic anthropologist), Linda Fairstein (Prosecutor Sex Crimes Unit), Dick Francis (jockey), Stieg Larsson (journalist), David Lodge (university professor), etc. ${ }^{7}$ A number of well-known FASP authors are also peer-recognised domain experts and publish non-fiction works of reference, e.g., Tom Clancy (Submarine: A Guided Tour Inside a Nuclear Warship, 1993; Fighter Wing: A Guided Tour of an Air Force Combat Wing, 1999, etc.), Iain Pears (The Discovery of Painting, 1989), Linda Fairstein (Sexual Violence, 1993), Kathy Reichs (Forensics Osteology: Advances in the Identification of Human Remains, 1986; Forensic anthropology in the 1990s, 1992), not to mention David Lodge's numerous books of literary criticism. Few readers would doubt the authenticity of specialised narrative proposed by authors whose sterling credentials are given all due paratextual prominence, as illustrated by the inside cover page of Kathy Reich's Fatal Voyage:

Kathy Reichs is a forensic anthropologist for the office of the Chief Medical Examiner, State of North Carolina, and for the Laboratoire de Sciences Judiciaires et de Médecine Légale for the province of Québec. She is one of only fifty forensic anthropologists certified by the American Board of Forensic Anthropology and is on the Executive Committee of the Board of Directors of the American Academy of Forensic Sciences. A professor of anthropology at the University of North Carolina at Charlotte, Dr. Reichs is a native of Chicago, where she received her Ph.D at 
Northwestern. She now divides her time between Charlotte and Montreal and is a

frequent expert witness at criminal trials. (2002)

\subsection{The specialist FASP reader}

19 At the other end of the spectrum is the specialist reader who is a professional or expert in the field of the fictionalised specialism and may subsequently be considered to be an involved or critical reader, as opposed to the casual reader mentioned above.

The idea of a specialist FASP reader gives rise to the question of why doctors would read Robin Cook, lawyers John Grisham, scientists Michael Crichton, etc. - and the answer would of course be, for exactly the same reasons that university teachers read David Lodge! The reasons evoked - self-knowledge, recognition, amusement, curiosity, etc. - present an interesting line of enquiry, but in the context of this discussion, it is the specialist reader's high degree of familiarity with the specialism which is of interest.

Borrowing from readership studies, the specialist reader may be comprehended in terms of "the ideal reader" defined by the University of Cumberland's online Glossary of Literary Terms as "A hypothetical reader who possesses the competence to understand all parts of the text with clarity." Certain aspects of Stanley Fish's controversial concept of the "informed reader" may also bear relevance to the specialist FASP reader.

The informed reader is [...] a competent speaker of the language out of which the text is built up, and is in full possession of the 'semantic knowledge that a mature listener brings to the task of comprehension.' This includes knowledge (that is, experience both as a producer and comprehender of lexical sets, collocation, probabilities, idioms, professional and other dialects, etc.). (Fish cited in Iser 1978:

31)

While Fish's "informed reader" is conceived largely in terms of reader self-observation during processing of narrative, those working in the field of English for Specific Purposes (ESP) and genre analysis and familiar with the Swalesian (1990) concept of "genre" and "discourse communities", may find some points of analogy between "specialist FASP reader" and "informed reader", all the more so as Fish situates the latter in "an interpretive community" composed of readers who share the same interpretive strategies.

If the author's status as an expert serves to sanction the naïve reader's dependence, in the case of the specialist reader, it is a peer-to-peer situation of communication as regards the substrat professionnel at both semantic, pragmatic and conceptual levels. The symmetrical nature of this specialist author/specialist reader equation is, however, the subject of some debate today. Given that the professional-turned-author often no longer actively exercises his (former) profession - How often does John Grisham plead? When did Robin Cook last practise as a doctor? When did David Lodge last attend an English department meeting? - and, given the numerous and rapid changes overhauling all professional areas of life today, the question arises as to whether the professional-turned-author is still on the cutting edge of his specialism compared to readers who are active professionals.

Having established the two opposed tapering ends of the FASP readership spectrum with regard to subject-domain accessibility, we now come to the area in between. This category represents the bulk and critical mass of FASP readership and is composed of lay readers who may be defined in terms of the average college-educated layman. Such 
readers often seek to enhance the "futile" pleasures of light reading through the acquisition of knowledge, and the FASP, with its "readily assimilable factual truth" (Ken Gelder, 2004: 93), fulfils the dual aspiration admirably.

Unlike the naïve reader, certain lay readers bring to their FASP reading a pre-existing degree of familiarity with the substrat professionnel. Such readers, whose information is essentially self-acquired, may be subsumed into two main categories, the informed FASP reader and the knowledgeable FASP reader.

\subsection{The informed FASP reader}

Self-acquisition modes of information are multifarious. ${ }^{9}$ On a personal level, sources may be experiential and an often cited example in this context is the case of medicine: an illness, experienced personally or vicariously, inevitably increases the individual's capital of knowledge regarding a given disease beyond what is normally expected of the average layman. Hobbies and leisure activities operate in the same way.

On a less personal plane, the news media remain a rich source of informationgathering, as for example, in the case of the non-specialised written press with its regular columns on such specialised domains as health, finance, the environment, art, energy, etc. The autodidact's paramount source of knowledge, however, is undeniably that information highway and defining pillar of the knowledge-based society, the Internet, with its double-click availability of duly popularised information on any known subject.

Finally, there is the significant role played by the entertainment media, which includes FASP, whether print, television or cinematic. The power of the FASP to disseminate knowledge is one of the underlying principles of education-entertainment or "edutainment", whether overtly didactic in the form of didacticised FASP (Isani 2004: 33-34) or not. In this respect, a recent study relative to medical television FASP provides statistical evidence confirming the high correlation between fictional exposure and audience awareness. In 2008, The Henry Kaiser Family Foundation, "which has long worked to incorporate health messages into popular television shows" (2008: 2), published a report entitled Television as a Health Educator: A Case Study of Grey's Anatomy on an experiment conducted to study the correlation between the medical FASP television series and public awareness before and after an episode containing a deliberately embedded flash item of medical information. The survey revealed that public awareness regarding the item jumped from $15 \%$ before viewing to $61 \%$ after viewing (2008: 8).

FASP readers who remain loyal to a particular subgenre inevitably build up a certain capital of information relative to their preferred substrat professionnel, which greatly enhances accessibility to the related specialised discourse, concepts and culture. In this respect however, it is important to underline that, though the autodidact FASP reader may be considered a relatively informed reader with regard to a specific substrat professionnel, given the unguided, unmediated and unstructured nature of acquisition, the result tends towards an accumulation of fragmentary and heteroclite facts which it would be more apt to qualify as a random collection of information than a coherent body of knowledge. 


\subsection{The knowledgeable FASP reader} the informed FASP reader and the expert knowledge of the specialist reader, there is a category of reader whose familiarity with the fictionalised specialism is based on a more systemic and constructed mode of acquisition.

31 interests of this journal's readers and the didactic stakes underlying FASP studies, we
now turn our attention to academe to study the FASP profile of the university student and the ESP teacher.

\section{The student}

The student is referred to here with regard to his field of specialisation. A key characteristic regarding the student's speciality knowledge is that it is, by definition, part of an ongoing process as he progresses from fresher to graduate, from novice to specialist.

During the successive phases of acquisition, it is quite possible that an informed FASP reader's degree of familiarity with a particular subject-domain may, at a given point, be equal to, or even surpass, that of the student whose future specialism it represents. In this respect, legal FASP is a case in point. Since high school curricula in Europe seldom include law, an informed FASP reader may quite well possess greater familiarity and critical distance than a first- and second-year law student regarding certain areas of fictionalised law, thus blurring the lines between the two categories of FASP readers.

The fundamental difference between the informed reader's familiarity with the specialism and that of the student concerns acquisition modes: in sharp contrast to the autodidact reader's fragmentary and disorganised self-acquired knowledge, the student possesses a more constructed mode of academic acquisition based on a systemic, analytic and mediated approach resulting in a reasoned body of knowledge, a parallel very reminiscent of the early distinction made by Stephen Krashen (1981) between language learning and language acquisition.

\section{The ESP teacher}

The ESP teacher's relation to the learner's field of specialisation is a permanent subject of debate and characterised by a certain ambivalence, as reflected in Hutchinson \& Waters' (1987) classic work which states, on the one hand that

ESP teachers do not need to learn specialist subject knowledge. They require three things only: a positive attitude towards the ESP content; a knowledge of the fundamental principles of the subject area; an awareness of how much they probably know. (1987: 163)

If there is to be meaningful communication in the classroom, it is essential that there is a common fund of knowledge and interest between teacher and learner. This implies inevitably that the ESP teacher must know something about the subject matter of the ESP materials. (1987: 163) 

that of the informed FASP reader's is that its acquisition is grounded in a methodological approach and subjected to critical analysis skills acquired during academic years. In her book, Developing Scientific Literacy Using Science Fiction, Julie E. Czerneda defines the competences required of "a scientifically literate person" in terms of the following descriptors:

A scientifically literate person

- identifies the scientific issues underlying personal and societal decisions.

- expresses views on those issues in appropriate scientific terms.

- evaluates the quality of scientific information by considering both its source and the methods used to obtain this information.

- makes and evaluates arguments based on evidence and applies conclusions from such arguments appropriately.

- reads and understands articles about science in the popular media, and discusses with peers the validity of their conclusions.

- distinguishes between what is and what is not a scientific idea. (1999: 2) 
to fictional specialised narrative rarely constitutes an insurmountable obstacle for ESP language teachers.

And finally, the ESP teacher is not alone. One paradoxical factor which ensures that the teacher's self-acquired speciality knowledge is sounder than that of other autodidact FASP readers is that its acquisition is not totally unguided: in certain areas, the ESP learner, that future subject-domain specialist, serves as mentor and corrector regarding speciality knowledge, a role assumed all the more competently and naturally during the final years of academic maturing.

To conclude with this part of the analysis, we would like to examine the concept of the "intended reader" - the reader the author had in mind while creating the narrative proposed by readership studies in relation to reader accessibility to the specialised constructs of the substrat professionnel. Given the wide-ranging readership profiles, the question arises as to whether the concept is operational with regard to the FASP author. Though, as we saw earlier with Neil Griffith's Saving Caravaggio, certain FASP authors do indeed have "an intended reader" in mind, the multi-profile nature of the genre's readership induces FASP authors to adopt a broader perspective and "be something to all men". In the following part of this study, we examine how the author accomplishes the feat of producing specialised narrative text which caters to both ends of the FASP reader accessibility spectrum.

\section{Bridging the accessibility gap}

Concepts from discourse and conversation analysis shed light on how specialised fictional narrative juggles with its contradictory textual tensions through analysis of how authors distribute enunciative roles and stage discourse to adapt to the communicative constraints of reader accessibility within the bounds of the fictional and narrative credibility.

Let us take the example of a simple dialogue between two fictional protagonists. In a typical dyadic situation of communication, there would, at first glance, appear to be two clearly identified interlocutors, the addresser and the addressee. Conversation analysis, however, reveals a far more complex situation of communication and, as Catherine Kerbrat-Orecchioni (1990: 92) argues, to explain her concept of the "communicative trope" regarding primary, secondary, direct and indirect addressees, "un allocutaire peut en cacher un autre."10 In this respect, Erving Goffman's founding work in conversation analysis highlights the diversity and intricacy of participant and recipient roles in dyadic and polyadic exchanges, since "an utterance does not carve up the world beyond the speaker into precisely two parts, recipients and non-recipients, but rather opens up an array of structurally differentiated possibilities [...]." (1981:137)

On the basis of the premise that "when a word is spoken, all those who happen to be in perceptual range of the event will have some sort of participation status relative to it" (1981: 3), Goffman identifies several possible categories of addressors and addressees participant/recipient, primary/secondary, ratified /unratified, addressed/unaddressed - according to their participatory status during a particular "moment of talk" (1981: 131). Ratified addressed participants are those participants formally involved in the exchange, while "adventitious participants" are "bystanders", either "overhearers" or 
"eavesdroppers", whose role is generally that of witness. This "participatory framework" is summed up in the following flow chart (figure 1).

Goffman's work reflected real life situations. Fictional contexts present a more complex situation in that a preliminary distinction needs to be made between two levels of parallel discourse, and therefore two categories of participants and recipients, fictional and narrative. Although fictional addressees are more visibly identified due to their status as protagonists, the onus of authorial strategies to enhance reader accessibility is usually borne by the more implicitly identified narrative addressees. One example of such a narrative addressee is what narratologists call "the narratee" defined by Abrams (1999: 173) as "the explicit or implied person or audience to whom the narrator addresses the narrative," and who is distinct from the reader, as becomes clear in the case of first-person narratives. Transposed in terms of Goffman's taxonomy, and in spite of the fact that narrative addressees are not active participants in the exchange, they are nevertheless ratified as addressed recipients.

Fig. 1. Erving Goffman's Multi-level Recipients adapted from Kerbrat-Orecchioni (1990: 86)

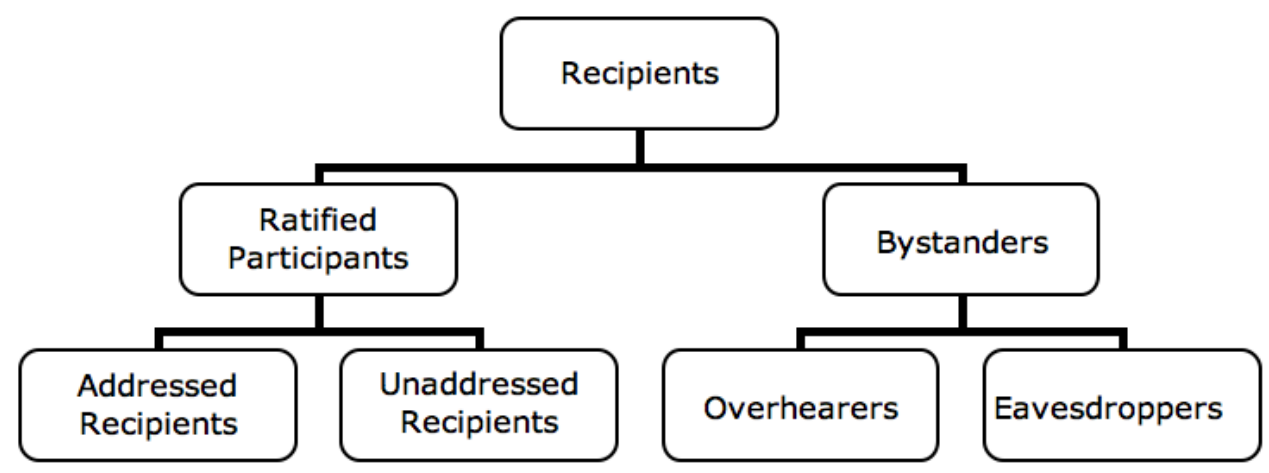

How does a FASP author use these different categories of recipients to achieve his oxymoronic ends? Some clues may be found by viewing the status of fictional and narrative addressees in terms of ratified participants and addressed/unaddressed recipients, and analysing the distribution of enunciative roles (the expert, the novice, the mediator, the instructor, etc.) and the communicative intentions underlying their utterances. In this respect, we propose to study extracts from two mainstream substrats professionnels, law and forensics.

\section{Legal FASP. the M'Naghten Rule}

50 As discussed earlier, reader accessibility may be hampered by unfamiliarity with specialised language, concepts or culture. This extract, from John Grisham's first legal FASP, A Time to Kill (1992) centres on a legal concept regarding the insanity plea, familiarly known as "the M'Naghten Rule", the official version of which is phrased in traditionally incomprehensible "legalese":

The British Trial of Lunatics Act of 1883 provides that: Where in any indictment or information any act or omission is charged against any person as an offence, and it is given in evidence on the trial of such person for that offence that he was insane, so as not to be responsible, according to law, for his actions at the time when the act was done or omission made, then, if it appears to the jury before whom such 
person is tried that he did the act or made the omission charged, but was insane as aforesaid at the time when he did or made the same, the jury shall return a special verdict that the accused is not guilty by reason of insanity. <Duhaime.org/ LegalDictionary/M/MNaghtenRules.aspx>

51 In A Time to Kill, the author exploits the fictionalisation of this legal principle in multiple ways. At extra-textual level, this specialised concept, unknown to the general public, serves to confirm the author's status as a specialist; at discoursal level it is used to authenticate the substrat professionnel by elucidation through replication of trial procedure and expert witness examination discoursal canons; at narrative level, it is used to "tease" the reader through use of the classic literary device based on recurrent allusion and delayed elucidation (after 442 pages in this case); and finally, at textual level, it allows the author to deploy narrative strategies and enunciative roles to produce a distinctly more reader-friendly version than the one referenced above.

Fig. 2. Extract from John Grisham's A Time to Kill (1992: 443-445)

\begin{tabular}{|c|c|}
\hline [1] & $\begin{array}{l}\text { "Dr Bass, are you familiar with the criminal responsibility test relative to the M'Naghten } \\
\text { Rule?" Jake asked. }\end{array}$ \\
\hline [2] & "I certainly am!" Bass replied with a sudden air of superiority. \\
\hline [3] & "Would you explain this rule to the jury?" \\
\hline [4] & $\begin{array}{l}\text { "Of course. The M'Naghten Rule is the standard for criminal responsibility in Mississippi, as in } \\
\text { fifteen other states. It goes back to England, in the year 1843, when a man by the name of } \\
\text { Daniel M'Naghten attempted to assassinate the prime minister, Sir Robert Peel. He mistakenly } \\
\text { shot and killed the prime minister's secretary, Edward Drummond. During his trial the } \\
\text { evidence plainly showed M'Naghten was suffering from what we would call paranoid } \\
\text { schizophrenia. The jury returned a verdict of not guilty, by reason of insanity. From this the } \\
\text { M'Naghten Rule was established. It is still followed in England and sixteen states." }\end{array}$ \\
\hline [5] & "What does the M'Naghten Rule mean?" \\
\hline [6] & $\begin{array}{l}\text { "The M'Naghten Rule is fairly simple. Every man is presumed to be sane, and to establish a } \\
\text { defense on the ground of insanity, it must be clearly proven that when the defendant did what } \\
\text { he did he was laboring under such a defect of reason, from a mental disease, that he did not } \\
\text { know the nature and quality of the act he was doing, or if he did know what he was doing, he } \\
\text { did not know it was wrong." }\end{array}$ \\
\hline [7] & “Could you simplify that?" \\
\hline [8] & "Yes. If a defendant cannot distinguish right from wrong, he is legally insane." \\
\hline
\end{tabular}

The semblance of a simple dyadic exchange between fictional ratified direct addressor and addressee is misleading. Also involved is a third fictional addressee who never speaks but is a fully ratified addressed recipient and explicitly identified as such: the lay jury. The enunciative status of a jury, whether real or fictional, is ambiguous since, though its silence prevents it from being "heard" as an active participant, it is nonetheless the recipient towards whom all discourse converges. Such situations of communication are not infrequent, as Patrick Charaudeau points out: 
[Theatre, radio and television talk shows] put various participants into discussion with one another and encourage verbal exchange animated by a presenter who asks them questions. This device puts the participants into contact with a 'present but absent' third: the public. We can therefore hypothesize that each speaker in the situation knows that he or she is being watched and listened to by the third party, and the exchange is directed toward this third party via the other interlocutors. (2002: 302) lexicon and locution in scientific specialised narrative. The extract analysed, a 'hi-tech' forensics FASP, reveals a wider cast of addressees and a more intricate distribution of narrative and discoursal roles designed to facilitate reader accessibility. As in the preceding legal FASP example, at fictional level the extract represents an apparently dyadic exchange between two colleagues, a forensics paleoanthropologist and a police officer. However, both participants also occupy enunciative positions at narrative level, the protagonist that of purveyor of specialised discourse, and the police officer that of the non-specialist facilitator of vulgarised discourse. the narratee (all the more present in this first-person narrative) who, considering the nature of the discourse of which he is the recipient, may be presumed to be a nonspecialist; and finally, the invisible but nevertheless primary target of this elaborate discoursal structure, the lay reader himself. It is the multi-layered discourse between the fictional and narrative recipients and their enunciative roles as specialists and nonspecialists which allows for textual interweaving of scientific discourse and its vulgarised version. 
Fig. 3. Extract from Kathy Reichs, Death du Jour (1999: 91-92)

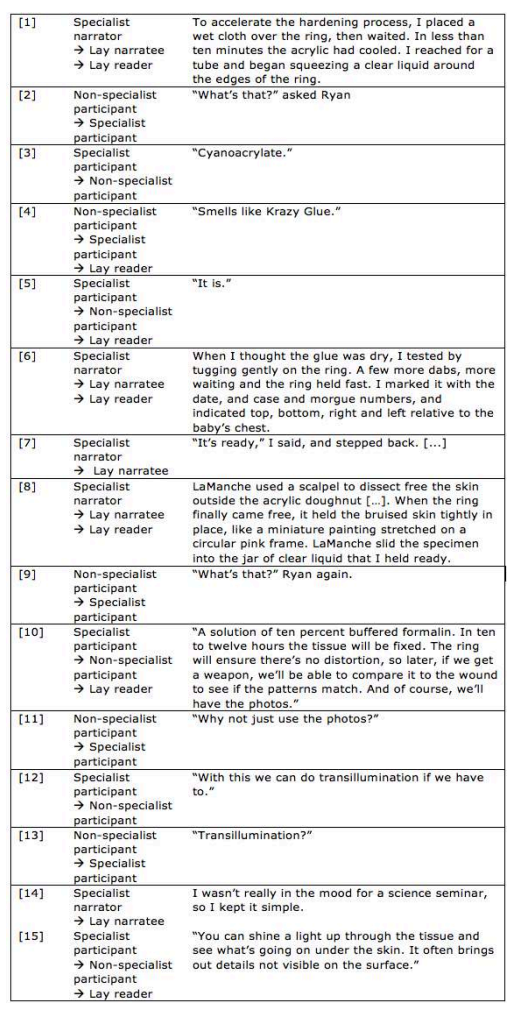

57 From a perspective of quantitative analysis, we note that no less than seven - [1] [4] [5] [6] [8] [10] [15] - out of the fifteen sequences which compose the extract are devoted to enhancing reader accessibility. From a perspective of qualitative analysis, we note the dual function of the specialist narrator's unmediated discourse addressed to the lay narratee [1] [6] [8] which relates the action taking place in simple declarative statements of fact ("I placed a wet cloth...", "I reached for a tube...", "When I thought the glue was dry...", "LaManche used a scalpel..."), and is also the voice that describes the technical processes and procedures; we note that, in spite of being the specialist participant, these exchanges are delivered in a relatively accessible didactic textbooklike register, suggesting a recipient who is a fusion of the fictional narratee and the lay reader.

Curiously, the technical lexicon and locution do not precede the non-specialist participant's naïve questioning but appear in response to it, raising the question of whether it is not related to the specialist's subliminal need to "show-off" in front of the novice. The novice participant is a key element in the construction of reader accessibility: as a visual observer of the scientific processes and procedures being demonstrated, his is the complex enunciative role of eliciting both the specialised text and its vulgarised version, generating an alternating pattern of specialised/vulgarised discourse and thus allowing the same detail to be expressed in two different registers, as may be observed in exchanges [3] ("Cyanoacrylate") and [4] ("Smells like Krazy Glue").

The question of register is raised in the text itself in a metadiscursive [14] aside addressed by the narrator to the narratee concerning the process of transillumination during which the specialist narrator rejects the so-called "science seminar" register in favour of a "simple" register: the informal and accessible syntactic and lexical register 
of the fictional definition presents a sharp contrast to the formal register of peer-topeer discourse, as may be observed by comparing the two texts below.

Fig. 4. Comparative texts on Transillumination

\begin{tabular}{|l|l|}
\hline $\begin{array}{l}\text { Mosby's Medical Dictionary, } 2009 \text { (Elsevier) } \\
\text { <http://medical-dictionary/ } \\
\text { thefreedictionary.com> }\end{array}$ & $\begin{array}{l}\text { Reichs, Kathy, Death du Jour (1999: } \\
92)\end{array}$ \\
\hline $\begin{array}{l}\text { Transillumination: The passage of light through body tissues } \\
\text { for the purpose of examining a structure interposed between } \\
\text { the observer and the light source. A diaphanoscope is an an shine a light up through } \\
\text { instrument introduced into a body cavity to transilluminate } \\
\text { tissues. }\end{array}$ & $\begin{array}{l}\text { "You the the skin. It often brings out } \\
\text { details not visible on the surface." } \\
\text { [15] }\end{array}$ \\
\hline
\end{tabular}

\section{Conclusion} which determines reader accessibility to specialised narrative fiction, and highlights two essential traits of FASP readership: firstly, as the foregoing analysis has sought to establish, the multi-profile aspect of the readership discussed and, secondly, its highly protean nature since the equation between reader accessibility and specialised text is defined by a permanent state of evolution shaped by diachronic and synchronic mobility.

In a diachronic perspective, it is obvious that the reader does not approach his second, third or fourth specialised text, whether fiction or non-fiction, with the same innocence as he did his first, and that his capital of speciality knowledge increases with each successive text. In the case of specialised fictional narrative, however, reader accessibility must also be viewed in a synchronic approach in that readers, even if they do have a preferred specialism subset, rarely limit their reading of the genre to one specific specialism only, and that legal FASP readers also read journalism, art, economic and science FASP.

Another aspect which modifies reader profiles is mutations within the genre itself, notably regarding the evolution of the canonical dominance of the substrat professionnel towards a certain hybridisation caused by the increasing integration of adjunct specialisms, or adstrats professionnels. Multiple specialisms are an intrinsic characteristic of certain subgenres such as journalism FASP, whose symbiotic nature, characteristic of the profession itself, makes it dependent on another field of human activity in order to exist. In a more transgressive approach, hitherto conventional FASP authors appear to be moving towards hybridisation as evidenced by John Grisham's The Last Juror (2004) in which the dominant substrat professionnel, contrary to what the title may suggest, is journalism and not law. Or again, Arturo Pérez-Reverte's The Flanders Panel (2003) ${ }^{11}$ in which art runs parallel to chess. In view of such subgeneric overlapping, the FASP reader is increasingly exposed to the uncharted territory of unfamiliar subgenres. In this more overall generic perspective, reader profiles mutate as they are defined and redefined in relation to different FASP subgenres. Accordingly, when confronted with 
the unfamiliar knowledge parameters of a new substrat professionnel, the specialist reader of a given FASP subgenre may quite well find himself relegated to the status of a naïve reader, highly dependent on authorial strategies to access the specialised narrative.

\section{BIBLIOGRAPHY}

\section{Primary References}

Grisham, John. 1992. A Time to Kill. London: Arrow Books.

Grisham, John. 2004. The Last Juror. London: Century.

Pérez-Reverte, Arturo. 2004. The Flanders Panel. Trans. Margaret Jull Costa. London: Vintage.

Reichs, Kathy. 1999. Death du Jour. London: Arrow Books.

Reichs, Kathy. 2002. Fatal Voyage. London: Arrow Books.

\section{Secondary References}

Abrams, M. H. 1999. A Glossary of Literary Terms. $7^{\text {th }}$ edition. Boston: Heinle \& Heinle.

Beacco, Jean-Claude, Chantal Claudel, Marianne Doury, Gérard Petit and Sandrine Reboul-Touré. 2002. "Science in media and social discourse: new channels of communication, new linguistic forms ». Discourse Studies 4/3, 277-300.

Bourdieu, Pierre. 1992. Les règles de l'art. Genèse et structure du champ littéraire. Paris: Seuil.

Charaudeau, Patrick. 2002. "A communicative conception of discourse". Discourse Studies 4/3, 301-378.

Czerneda, Julie. 1999. Developing Scientific Literacy Using Science Fiction. Toronto, Canada: Trifolium Books Inc.

Derry, Charles. 1988. The Suspense Thriller. Jefferson, NC: McFarland.

Gelder, Ken. 2004. Popular Fiction. The logics and practices of a literary field. New York, NY: Routledge. Genty, Stéphanie. 2009. "Apparent truth and false reality: Michael Crichton and the distancing of scientific discourse”. ASp 55, 95-106.

Goffman, Erving. 1981. Forms of Talk. Oxford: Basil Blackwell Publisher.

Hutchinson, Tom and Alan Waters. 1987. English for Specific Purposes. A Learning-Centred Approach. Cambridge: Cambridge University Press.

Isani, Shaeda. 2004. "Popular films as didactic supports in ESP teaching - selection criteria \& ethical considerations". Aspects de la fiction à substrat professionnel, Michel Petit (dir.) en collaboration avec Shaeda Isani. Coll. Travaux 20.25. Bordeaux: Université Bordeaux 2, 25-36.

Isani, Shaeda. 2004. "Interview with Iain Pears". In Michel Petit et Shaeda Isani (dir.), Aspects de la fiction à substrat professionnel. Coll. Travaux 2025. Bordeaux: Université Bordeaux 2. 
Isani, Shaeda. 2006. « Revisiting cinematic FASP and English for legal purposes in a self-learning environment ». Les Cahiers de l'APLIUT “Cinéma et langue de spécialité” 25/1, 26-38.

Iser, Wolfgang. 1978. The Act of Reading. Oxford: Routledge \& Kegan Paul, Ltd.

Kerbrat-Orecchioni, Catherine. 1990. Les interactions verbales. Paris: Armand Colin.

Krashen, Stephen D. 1981. Second Language Acquisition and Second Language Learning. London: Prentice-Hall.

McCracken, Scott. 1998. Pulp: Reading Popular Fiction. Manchester: Manchester University Press.

Petit, Michel. 1999. “La fiction à substrat professionnel: une autre voie d'accès à l'anglais de spécialité”. ASp 23/26, 57-81.

Robinson, Pauline. 1991. ESP Today: A Practitioner's Guide. Hemel Hempstead, GB: Prentice Hall International.

Swales, John. 1990. Genre Analysis. Cambridge: Cambridge University Press.

The Henry J. Kaiser Family Foundation Report. 2008. Television as a Health Educator: A Case Study of Grey's Anatomy. <www.kff.org>. Retrieved 12/07/09.

\section{Online References}

“Transillumination". Mosby's Medical Dictionary. <http://medical-dictionary/thefree dictionary. com>. Retrieved 12/07/09.

“M’Naghten Rule”. Online Legal Dictionary. <Duhaime.org/LegalDictionary/M/MNaghten Rules. aspx>. Retrieved 16/04/09.

“The ideal reader". A Glossary of Literary Terms. University of Cumberland. <http://english. ucumberlands.edu/litcritweb/glossary.htm>. Retrieved 14/04/09.

\section{NOTES}

1. Though a number of exemplary FASP novels were written before this period, the genre attained sufficient critical mass to warrant generic status in the 1980 s.

2. Even if there is, as Charles Derry says, "tremendous confusion and disagreement as to what exactly the term 'thriller' refers to" (1988: 19), in this context the term subsumes such generic classifications as "suspense", "crime fiction", "murder mysteries", etc.

3. Viewed in a cross-cultural perspective of readership, it may even be wondered whether texts drawn from mainstream science disciplines do not represent an interesting common denominator in that, being relatively culture-free, they are accessible to an intercultural crosssection of readership irrespective of culture, generation or gender, as for example, in the case of mathematics, the so-called universal language.

4. Even though law is a very culture-specific discipline, legal FASP is an atypical area of reference in this respect and poses problems compounded by the fact that, for reasons related to the culture of civil law, the European lay public remains largely unaware of its source legal culture and, through exposure to Anglo-centric legal FASP, adopts fictionalised Anglo-American legal culture as its own. (Isani 2006).

5. This also helps explain the publishing paradox that the highly technical nature of a fictionalised narrative - and its presumed low reader accessibility - is not an obstacle to the popularity of the genre. A relatively culture-free scientific substrat professionnel is perhaps more accessible than a culture-specific one, which fact would partly explain why such technically challenging FASP thrillers as Tom Clancy's techno-military FASP, Michael Crichton's scientific 
FASP, or again Kathy Reichs and Patricia Cornwell's forensics FASP, are all bestsellers with far more copies sold worldwide than the more reader-friendly art FASP.

6. Publishers conduct surveys regarding sex, age, level of education, income group, profession, etc., of readers of particular segments of the literary market to draw up readership profiles. The FASP is too recent, too vast and too diversified a phenomenon to carry out such surveys at the present stage, which is regrettable since there would no doubt be interesting conclusions to be drawn regarding correlations between the age and level of education, for example, and accessibility to the specialised fictional environment. In view of this, the present typology is based on a more theoretical approach.

7. Other authors, such as Tom Clancy, Denise Mina, Arthur Hailey, etc., invest in extensive research to guarantee the authenticity of the fictionalised specialism of their fiction.

8. According to Wolfgang Iser, "the ideal reader" is generally the philologist or the critic, if not the author himself.

9. In spite of risk of confusion with Stanley Fish's "informed reader", we maintain the qualification for this category of reader on the basis of the more generic acceptation of "having or showing knowledge about a particular subject or situation" (Oxford English Dictionary 2000: 666). To minimise confusion, however, we shall specify "informed FASP reader" in the context of this paper.

10. Loosely translated as, "One addressee may hide another", a reference to a well-known road sign in France, "Un train peut en cacher un autre" or "One train can hide another".

11. Spanish title, La Tabla de Flandes (1990).

\section{ABSTRACTS}

This paper seeks to establish how lay readers access specialised fictional narrative. After an overview of specialised fictional narrative or FASP as a genre, it presents samples of specialised linguistic, conceptual and cultural constructs that may hamper reader accessibility. The study then goes on to propose a typology of four reader profiles defined in relation to accessibility to specialism-related fictional text, ranging from the naïve reader to the specialist and in-between. The second part of the study uses Goffman's participatory framework to analyse authorial vulgarisation strategies used in legal and forensic fiction to render specialised text both technical and accessible. To conclude, the author underlines the instability of such profiles due to constant diachronic and synchronic evolution of the genre reader.

Cet article cherche à comprendre comment le lectorat profane accède à la fiction spécialisée. Après une brève introduction à la FASP, l'article présente des exemples d'éléments linguistiques, conceptuels et culturels spécialisés qui peuvent constituer des entraves à l'accessibilité au texte spécialisé pour le lecteur profane. L'auteure propose ensuite une typologie de quatre profils de lecteur définis en fonction de leur rapport avec le récit spécialisé, allant du lecteur naif au lecteur spécialisé. Dans une deuxième partie, l'auteure s'appuie sur les théories de Goffman en analyse conversationnelle pour étudier les stratégies de vulgarisation déployées en FASP juridique et scientifique destinées à rendre un texte à la fois technique et accessible. Pour conclure, elle souligne le caractère instable de tels profils en raison de l'évolution diachronique et synchronique des connaissances du lecteur par rapport au substrat professionnel. 
INDEX

Mots-clés: FASP, lecteur profane, lectorat, récit fictionnel spécialisé, vulgarisation

Keywords: FASP, fiction narrative, lay reader, popularisation, specialised readership

\section{AUTHOR}

\section{SHAEDA ISANI}

Shaeda Isani is a full professor with the Department of Applied Linguistics, University of Grenoble, France. Her current research interests lie in the field of specialised discourse and cultures (law and economics), fictional representations and perceptions of professional and specialised environments. shaeda.isani@u-grenoble3.fr 